\title{
Planning for Education Development Projects: Experiences from the Application of O\&OD Approach in Kiroka Ward, Morogoro Rural District
}

\author{
Elias Mseti \\ Assistant Lecturer \\ University of Dodoma \\ School of Humanities and Social Sciences, Tanzania \\ E-mail: msetielias@gmail.com \\ Eliza Mwakasangula \\ Senior Lecturer \\ Mzumbe University \\ School of Public Administration and Mgt, Tanzania \\ E-mail: efaty@mzumbe.ac.tz
}

Received: Nov. 28, 2018 Accepted: Jan. 8, 2019 Online published: Jan. 31, 2019

doi:10.5296/ijhrs.v9i1.14305 URL: https://doi.org/10.5296/ijhrs.v9i1.14305

\begin{abstract}
Participatory planning has been regarded as an approach to enhance development through popular participation of local people in setting local plans and preferences. In an effort to make participatory planning a reality, the Tanzanian government through President's Office Regional Administration and local government (PO-RALG) introduced Opportunities and Obstacles to development (O \& OD) with the aim of promoting bottom up planning process. The O\&OD approach was thus designed to promote community initiatives in the planning process as well as accelerating achievement of national development goals as per Tanzanian Development Vision 2025. Therefore, this approach functions as an essential approach to identify community preferences for developing local plans. Nevertheless, the empirical research shows that despite this initiative, the planning process is still top down. The O \& OD has not realized the intended objective. This study, therefore, examined the Planning for
\end{abstract}




\section{MInstitute ${ }^{\text {Mank }}$}

International Journal of Human Resource Studies

ISSN 2162-3058

2019, Vol. 9, No. 1

Education Development Projects by drawing experiences from the Application of O\&OD Approach in Kiroka Ward in Morogoro Rural District. The study used a case study design, drawing a total sample of 94 respondents including 14 key informants, 10 members of village council and 70 community members. Purposive sampling was used to select key informants; simple random sampling was used to select members of the village council and that snowball sampling was used to select community members. Primary data were collected through interviews, questionnaire and direct observation. NVIVO software for qualitative data analysis was used to analyze the in depth interviews while the questionnaires was analyzed using SPSS computer software. The quantitative analysis involved descriptive statistics such as frequencies and percentages which were presented in the form of tables and figures. The study found that, Education Development Planning (EDP) process started at the school committees, village council and village assembly. EDP in the two villages was made by community leaders. Community members were involved at the implementation stage. Therefore EDP did not follow O\&OD approach. This shows that participation for education planning in Kiroka and Kiziwa is conducted by leaders this affected education project since most of the projects were not implemented as villagers were not involved.

Keyword: opportunities and obstacles to development, participatory, planning, education, popular participation, community initiatives, projects

\section{Introduction}

Since independence, the government of Tanzania sought to have participatory planning so as to enable grass root people to participate in the decision making process (Max, 1991). Democratic local governments were established across the country for the purpose of extending services provision to the people and give the local people autonomy to planning and implementation (PMO-RALG, 2008). However the established local government did not bear fruits since planning and decision making powers were concentrated at central level (Oyugi, 1988). Until 1972 there was no participatory planning in local government as powers were concentrated at the center and local governments were implementing plans made at the central level rather than being representative body of government (Shivji\& Peter, 2003).

In 1996, the government embarked on Local Government (LG) reforms to improve participatory planning and service delivery. The guiding principle of local government reform was Decentralization by Devolution ( $\mathrm{D}$ by $\mathrm{D}$ ), whose main aim was to improve the performance of the public sector, increase the accountability and improve planning and implementation of the grassroots level (Shivji\& Peter, 2003).

In order to reach the aims of the development plans, as shown in the Tanzanian Development Vision 2025, planning was regarded to enhance development. In this sense, bottom-up planning was one of the main aspects of the LG reforms. The reform was intended to increase popular participation in setting local plans and local preferences. The underlying assumption was that, citizens conceive their own projects and plans implemented by the local people according to their preferences. Local communities have the information on the local needs. If these communities make plans to improve the local situation, and if these plans gain support, the chances that these plans are implemented and really cause some kind of development are 
considered higher (Chaligha, 2008).

Furthermore, in an effort to make community participatory planning a reality, the government through President's Office Regional Administration and local government (PO-RALG) introduced Opportunities and Obstacles to development in (O \& OD) (PO-RALG, 2005). O \& OD approach was developed in 2002 with the aim of creating a sense of ownership in the community plans.

The O\&OD approach was thus designed to promote community initiatives as well as to accelerate achievement of national goals in the Tanzanian Development Vision 2025. In the O\&OD planning process, the sub-goals in the Vision 2025 became a direct basis of setting specific objectives, under which planning items are identified such as opportunities, obstacles, interventions, costs and so on. Besides, the O\&OD was intended to promote the effective and efficient allocation of Local Government Capital Development Grants (LGCDG) as clearly elaborated in the Planning Guidelines for villages and Mtaa that the O\&OD is an essential approach to identify community preferences for which the LGCDG is disbursed (The United Republic of Tanzania (URT) 2006; PO-RALG, 2004). The researcher aimed at analyzing whether O\&OD has helped improve of education planning in Kiroka ward.

\section{Literature Review}

\subsection{The Concept of Planning, Participation and Community Participation}

\subsubsection{Planning}

The term planning has been defined differently depending in the context which it is used. Planning is defined as the process by which the organisation decides where it wants to be in the future (Certo, 2000). Planning here acts as a compass direction which informs the organisation where to pass in order to attain goals and have a better future. Planning is also the process by which an organisation, group of people or individual decides on some features course of actions (Omran, 2000). It is an effort whereby the management centralizes resource allocation sufficiently, social costs and benefits should be taken into account. The emphasis in this definition is put in allocation and distribution of resources to the different groups in society (Sirkin, 1968).

Planning is also defined as deciding in advance what is to be done. When a manager plans, he projects a course of action for further attempting to achieve a consistent co-ordinate structure of operations aimed at the desired results (Haimann, 1999). However in the words of Koontz and O' Donnell (1968) planning is an intellectual process, conscious purpose of course of action, the base of judgment on objectives, facts and considered estimates.

For the purpose of this study planning is seen as the process where a group of people sets objectives, identify available resources to achieve the objective over a specific period of time.

\subsubsection{Participation}

Participation is also defined as the process whereby disadvantaged people influences policy formulation, implementation and evaluation (Imparator \& Ruster, 2003). In this definition it 
is argued that people should be involved in all stages from planning stage to evaluation stage. Being involved the projects will be owned by the people themselves. All these definition emphasize on involving people in development projects. Some of the definition emphasize that citizens should be involved from planning to implementation of different projects and other definitions emphasize involving citizens in decision making process. For public participation to be true participation involving the community in decision making process from planning, implementation and evaluation process is critical.

\subsubsection{Community Participation}

Community participation is a term used to empower citizens (Arnstein, 1969). According to Arnstein participation is to empower local citizens participate in economic and political process affecting their lives (Ibid). It is the process where powerless local citizens are involved in setting objectives and policies, operation of programme, information sharing and tax allocation. Citizens participation is also defined as the process by which the community have power to influence public decisions, it is a democratic decision making process (Cogan $\&$ Sharpe, 1986). Mize further reveals that citizen's participation has a relationship to public decision making. He states that in participation citizens should have power to influence decisions (Mize, 1972).

\subsection{O\&OD Planning at Grassroots Level}

The planning process using O\&OD approach involves eleven steps which allow community members to priorities their preferences in logical framework, the steps are laid down in the community participatory planning process methodology rural process of 2007, the manual was promulgated by the PMO-RALG in 2007.

The activities in the manual start by writing an official letters to the village leadership informing them the intention of conducting O\& OD in the village, the letter should include the following things, stating the date of pre-visit, informing the village leadership to collect primary data for community planning and informing the village leadership to call the special meeting during the pre-visit day, the meeting should include key people to be invited, village leaders and other stakeholders (PMO-RALG, 2007).

After sending the official letter the facilitators will conduct a pre-visit. Pre-visit activity is the activity that allows facilitators to meet with village leadership, key people who have been invited, extension workers and other stakeholders to discuss O\& OD planning process. During this process the facilitators are suppose to explain to the village leadership and community members the Tanzania Development Vision 2015 which will form policy guide for the preparation of development plan.

After the explanation the community members should choose from main objective I and II of the TDV 2025, the objective that they consider to be priority for the development of their community plan (PMO-RALG, 2007). The facilitators during the pre-visit should also conduct the dialogue with village leaders, influential people, extension workers and other stakeholders. The dialogue should identify most effective way for community sensitization, identify participants for community planning process, prepare timetable for exercise and 
logistics, select the priority objectives from TDV 2015 to be used for community development plans, data collection, explain formation and use of focus group, village members should also sensitize to the village to attend the meeting so as to plan for their development using O\&OD and the village leaders should also informed to prepare the heads of housed for every hamlet (URT, 2007).

After the re-visit, facilitators together with community leadership choose the good way for community sensitization. The main aim to sensitize the community is to encourage them attend the extraordinary village assembly for launching O\&OD process. In the second day the community members that were sensitized in the dialogue with facilitators continues with sensitizing the village members on the importance of conducting participatory planning. The third step is to call the extraordinary village assembly for launching O\&OD participatory planning in the village. Facilitators will collect and check the forms of heads of household if filled in properly, the village assembly meeting should confirm on the objectives of high priority for the village, the meeting should select $6-10$ village resource persons who are familiar with the, village and it's Community. This team together with the Village Council will work in collaboration with facilitators in the process of preparing the Village plan, the meeting should form focus groups on the basis of hamlet, gender and age group, representation, the meeting should set criteria for household wealth ranking, Village sketch map should be drawn, household wealth ranking should be carried out, Village Executive Officer (VEO) continue to collect secondary data.

The fourth step involves data collection, community leaders and selected participants are informed about this activity, the data are collected after data collection the fifths step to the seven day the activity of these days will be discussion on TDV 2025 objectives and preparing the draft for community plans, focus group discussion is used in this activity. The discussion focuses on the selected objectives which were approved by general village assembly.

The eight step involves preparation of draft for community development, the draft is to be prepared by the village officer, facilitators and other selected members from the village, the draft shows the objectives for the village (what the village intends to achieve), resources to be used to achieve the objectives, the obstacles, the causes for the obstacles, measures to address the obstacles, steps of implementation of objectives, indicators for implementation, the costs to be covered by the community and the costs that cannot be covered by the community. The nine step is calling extraordinary village council meeting which sit to set priorities and prepare a three-year draft for community. The village assembly should receive and discuss objectives, opportunities, obstacles, causes and interventions as they came from the focus groups so as to prepare the Community Plan.

The ten step involves he extra ordinary village council meetings for making the three year plan. After that the plan is taken to the Ward Development Committee (WDC) for technical advice. The eleven step involve convening extraordinary village assembly to discuss and approve the community plans. After the plan approval the plan should be written in Manila paper and be posted on the notice board. 


\section{MInstitute ${ }^{\text {Macrothink }}$}

\section{Methodology}

\subsection{Study Area}

The study used Morogoro rural district as a case The study used Kiroka and Kiziwa villages as sub cases in Kiroka Ward of Morogoro District. The selection of these cases was based on the fact that the O\&OD has been used for five (5) years in those villages therefore the researcher wanted to see impact of O\&OD in education sector.

\subsection{Study Design}

\subsection{Study Population}

The populations of the study involved 3 respondents from council level these were 2 education officers in the district (both primary and secondary education officers), 1 District Planning Officer (DIPLO). 3 respondents from ward these were 1 Ward Executive Officer (WEO), 1 Ward Education Officer and 1 ward councillor. 10 village council members, 5 from Kiroka and 5 from Kiziwa. Four (4) head of schools these include 2 head teachers and 1 head master from Kiroka village and 1 head teacher from Kiziwa villages. Seventy village members these include 35 village members from Kiroka and 35 members from Kiziwa village.

\subsection{Sample Size and Sampling Techniques}

\subsubsection{Sample Size}

Regardless of the population size a sample or subsample of 30 cases is the bare minimum for studies in which statistical data analysis is to be done (Bailey, 1994). Therefore, a sample of 94 respondents was selected for the purpose of this study. These include 14 key informants. These respondents were selected by virtual of their position and believed to be potential and resourceful, to provide relevant information for the study, 10 village council members and 70 villagers.

\subsubsection{Sampling Techniques}

Purposive sampling was used to select 14 key informants who belonged in all categories, Council, Ward and Village level. In the Council level 2 education officers and 1 planning officer were selected. In the ward level 1 WEO, 1 ward education officer and 1 district councillor were selected. At the village level 2 VEOs (1 from Kiziwa and 1 from Kiroka), 3 head teachers (1 from Kiroka primary, 1 from Bondwa primary school,1 from Kiziwa primary school), 1 head master from Kiroka secondary school, 2 village chairpersons (1 from Kiroka village and 1 from Kiziwa village). Purposive sampling method was used to select 14 key informants. These respondents were selected by virtual of their position and believed to be potential and resourceful, to provide relevant information for the study. Respondents were selected basing on their position. Simple random sampling was used in selecting 10 village council members; this sampling technique was used for this group because any respondent selected from the group could be able to provide the same information which could be provided by another respondent. Therefore selecting any respondent from this group 


\section{Macrothink}

International Journal of Human Resource Studies

ISSN 2162-3058 2019, Vol. 9, No. 1

could help the researcher have relevant information. Snowball sampling was used to select 70 community members ( 35 from each village) who were included in the sample. This was only possible with the assistance of village chairpersons who helped the researchers to get the respondents from the two villages who were included in the sample.

\subsection{Data Collection Methods}

Questionnaire was administered to 70 villagers. This set of questions aimed at collecting information from villagers on the issues of community participation in development projects. Villagers were asked to rate community participation in EDP in respective villages. There searcher used in depth interviews to collect information from 14 key informants. This group gave insights into the process, of EDP using O\&OD, the key informant's interview helped the researcher to get opinion about respondents and how respondents were involved in the process. The researcher used direct observation to collect data from village council meetings and from schools. From village council meetings the researcher was observing participation of villagers in the meetings.

\subsection{Data Analysis}

In depths Interview were analysed using content Analysis; Questionnaire were analysed using Statistical Package for the Social Sciences (SPSS) computer programme. Descriptive statistics such as frequencies and percentages were determined and the information was presented in form of tables.

\section{Findings}

\subsection{Characteristics of Respondents}

Table 4.1. Background of respondents $(\mathrm{N}=94)$

\begin{tabular}{llllll}
\hline Category & Sex & Kiroka & Kiziwa & $\begin{array}{c}\text { District } \\
\text { Education } \\
\text { officers }\end{array}$ & $\begin{array}{c}\text { Ward } \\
\text { leaders }\end{array}$ \\
Villagers & Male & $28(40 \%)$ & $30(42.9 \%)$ & & \\
Village leaders & Female & $7(10 \%)$ & $5(7.1 \%)$ & & \\
Village council members & Male & $2(50 \%)$ & $2(50 \%)$ & & \\
& Male & $5(50 \%)$ & $4(40 \%)$ & & \\
Head of schools & Female & & $1(10 \%)$ & & \\
& Female & $2(50 \%)$ & $1(25 \%)$ & & \\
Ward leaders & Male & & $1(25 \%)$ & & $3(3.2 \%)$ \\
District leaders & Male & & & & \\
& Male & & & 1 & \\
Total & Female & & & 2 & \\
& Male & $35(37.2 \%)$ & $37(39.4 \%)$ & $2(2.1 \%)$ & \\
& Female & $9(9.6 \%)$ & $7(7.4 \%)$ & $1(1.1 \%)$ & \\
\hline
\end{tabular}




\begin{tabular}{|c|c|c|c|c|}
\hline Category & Villagers & $\begin{array}{l}\text { Village } \\
\text { leaders }\end{array}$ & Head of schools & $\begin{array}{l}\text { Council } \\
\text { members }\end{array}$ \\
\hline $24-33$ & $4(5.7 \%)$ & & & $1(10 \%)$ \\
\hline $34-43$ & $11(15.7 \%)$ & $1(15 \%)$ & & $3(30 \%)$ \\
\hline $44-53$ & $45(64.3 \%)$ & $3(75 \%)$ & $2(66.7 \%)$ & $5(50 \%)$ \\
\hline $54-63$ & $10(12.3 \%)$ & & $1(33.3 \%)$ & $1(10 \%)$ \\
\hline Total & $70(100 \%)$ & $4(100 \%)$ & $4(100 \%)$ & $10(100 \%)$ \\
\hline Category & \multirow{2}{*}{\multicolumn{2}{|c|}{$\begin{array}{l}\text { Standard seven } \\
60(85.7 \%)\end{array}$}} & Form four & Certificate \\
\hline Villagers $(\mathrm{N}=70)$ & & & $10(14.3 \%)$ & \\
\hline Village leaders $(\mathrm{N}=4)$ & \multicolumn{2}{|c|}{$1(25 \%)$} & $1(25 \%)$ & $2(50 \%)$ \\
\hline Council members $(\mathrm{N}=10)$ & \multicolumn{2}{|c|}{$6(60 \%)$} & $3(30 \%)$ & $1(10 \%)$ \\
\hline Total & \multicolumn{2}{|c|}{$67(79.8)$} & $14(16.6 \%)$ & $3(3.6 \%)$ \\
\hline
\end{tabular}

Out of 94 respondents who were recruited for this study, 17 (18.1\%) of them were female whereas $77(81.9 .3 \%)$ respondents were male. This implies that the larger sex of the respondent were male. This showed that in the two villages planning process is dominated by male. Out of 88 respondents who were recruited in the two villages $45(64.3 \%)$ villagers, $50 \%$ council members and $75 \%$ village leaders were in the age group between 44 and 53 and few $5.7 \%$ villagers were in the age group between 24 and $33.25 \%$ of village leaders, $60 \%$ of village council members and $85.7 \%$ of the villagers had attained primary education level. At least $20.2 \%$ respondents had attained secondary education. This implies that majority of people in the two villages visited has low education level. Low education level impacts participatory planning in EDP process. Most of the issues in the planning process require knowledge in different matters.

\subsection{Education Development Planning Process at Village Levels}

\subsubsection{Experiences from Kiroka Village}

The findings revealed that education planning process starts at the school committees. Members of the school committees identified the needs of improving school infrastructure by building new classes and toilets. The plans were discussed by members of school committees. Thereafter the schools committee proposes possible solution to the village council. The village council reviews the plans and finds solutions by either calling general village meetings or taking the plans to the council level.

Education development projects in the three primary schools (Kiroka and Bondwa) were taken to the village general assembly for approval. Although the interview were conducted separately but the account of the two head teacher in the education planning process matched. All head teacher in the primary schools were involved in the education planning process in their respective schools. According to the interview with the head teacher from Kiroka primary school it was reported that:

The need of building new classes and staff toilet started at school committees, the needs of having these classes, and discusses. Possible solutions were 
suggested, and then the plans were taken to the village council, the village council discussed the plans and tabled before the village meetings

Planning process at Kiroka secondary school is somehow different to the planning process at Kiroka and Bondwa primary schools. According to the second master from Kiroka secondary the plan for building laboratory was a top down plan. The plan came from the national level requiring every ward to construct laboratory. Kiroka secondary implemented the decision as it was directed. Also the new classes constructed under SEDP II programme was not discussed by either school community members or WDC. “...our plan always starts at school committees to WDC however some of the plans like laboratory construction were implemented as a directive from national level....".

According to the village chairperson and VEO, the education development planning process was not developed through O\&OD methodology. During planning process village leaders were not informed about necessary steps. The education plan was prepared by respective school committees and taken to the village council. The plans were discussed by village council. The council proposed possible solutions, the plans were taken to the village assembly for approval. According to the interview with VEO from Kiroka village it was stated that:

Education plan are prepared by school committees for example January this year Kiroka secondary school committee brought a plan of building dormitory and teachers houses, we received the plans, discussed them and taken them to the village council for approval.

The village chairpersons were not able to tell how the education development plans in Kiroka village are undertaken. They were also not familiar with the participatory planning using O\&OD methodology. In the interview with kitongoji chairperson from Kingobwe one respondent reported that: "...education plans are prepared either by the village, head teacher or school committees..." This indicates that, the village chairperson are not aware on the education development planning, this shows there is low planning knowledge among Vitongoji chairpersons.

According to the WEO, education plans for different primary and secondary schools in the village are implemented at the village level. The ward level implements education plans which are shared in the whole ward. The views from ward education officer were similar to the views of WEO. According to ward education officer education plans in all primary and secondary schools in respective villages in the ward are decided and implemented in the village level. The plans that require ward and district assistances are taken to the ward level for approval. These plans are compiled and taken to the district council. In the interview sessions with ward education officer it was stated that: "...I receive education plans from different primary and secondary schools, some of these plans are implemented at the village level while other plans are to be approved by the WDC..."

According to the O\&OD planning methodology 2007 WDC provides technical advices to the village plans. Regarding the statement WDC discuss plans which cut across the whole ward 
while education plans in the village are implemented in the village level. However it seems that some of the plans are not taken to the WDC for technical advices.

\subsubsection{The Experience from Kiziwa Village}

The findings shown that Education planning process starts at the school committees, members of the school committees identified the needs of improving school infrastructure by building staff office and students toilets. The plans were discussed by members of school committees, thereafter they were taken to the village council. The village council reviewed the plans took them to village assembly for approval. According to the interview with the head teacher from Kiziwa primary school it was reported that:

...the idea of building toilet staff office started at the school committee, also UWAWA and Right to play project started in the school committees. This was done so because the school committee has power of developing different activities in the school after getting approval from the village council... (Head teacher, Kiziwa primary school primary school: April 2017).

According to the village chairperson and VEO, the education development planning process was not developed through O\&OD methodology. During planning process village leaders were not informed about necessary steps. The education plan was prepared by respective school committees and taken to the village council. The plans were discussed by village council. The council proposed possible solutions, the plans were taken to the village assembly for approval. According to the interview with VEO from Kiziwa village it was stated that:

....we received different plans from school committees. We discuss them and take them to village assembly. Last year we received that plan of building new pupils toilet, the plan was discussed and taken to the village assembly for Approval. Oooooh I also remember Right to play project similar procedures were used... (VEO, Kiroka village: April 2014)

The chairpersons have never been involved in EDP as they live far away from the village. These vitongoji chairpersons they were not able to tell how the education development plans in Kiziwa village is conducted. They were also not familiar with the participatory planning using O\&OD methodology. In the interview with kitongoji chairperson from Kingobwe A it was reported that: "...education plans are neither prepared by community leaders nor community members, they are prepared by the government and taken to village..." According to the statement it seems the vitongoji chairperson are not aware on the education development planning, this shows there is low planning knowledge among Vitongoji chairpersons.

\subsection{Community Involvement in Education Development Projects}

\subsubsection{Experiences from Kiroka Village}

In assessing wheatear community members are involved in EDP in Kiroka village; questionnaires were administered to 35 community members. The communities were asked to 
rate different activities to be performed during EDP. The rating was done at the scale of strongly agree, disagree, agree and strongly disagree. The purpose for asking the questions was to assess whether the community members are involved fully in EDP. The results are presented in Table 4.5.

Table 4.5. Community involvement in EDP process $(\mathrm{N}=35)$

\begin{tabular}{lllll}
\hline \multicolumn{1}{c}{ Questions } & \multicolumn{1}{c}{$\begin{array}{c}\text { Strongly } \\
\text { agree }\end{array}$} & Agree & Disagree & $\begin{array}{c}\text { Strongly } \\
\text { disagree }\end{array}$ \\
\hline $\begin{array}{l}\text { I have been involved in setting priorities } \\
\text { for EDP }\end{array}$ & & $2(5.7 \%)$ & $3(8.6 \%)$ & $30(85.7 \%)$ \\
$\begin{array}{l}\text { EDP were formulated by village leaders } \\
\text { only }\end{array}$ & $28(80 \%)$ & $1(2.9 \%)$ & $1(2.9 \%)$ & $5(14.2 \%)$ \\
$\begin{array}{l}\text { Community members were involved in } \\
\text { collecting relevant data for EDP }\end{array}$ & $2(5.7 \%)$ & $18(51.4 \%)$ & $15(42.9 \%)$ & 0.00 \\
$\begin{array}{l}\text { Dialogue with facilitators to prepare } \\
\text { education planning was conducted }\end{array}$ & 0.00 & 0.00 & $30(85.7 \%)$ & $5(14.2 \%)$ \\
$\begin{array}{l}\text { Sensitization for EDP was conducted } \\
\text { Extra ordinary village assembly for }\end{array}$ & 0.00 & $31(88.6 \%)$ & $4(11.4 \%)$ & 0.00 \\
$\begin{array}{l}\text { launching EDP was conducted } \\
\text { Extra ordinary village assembly for } \\
\text { approval was conducted }\end{array}$ & $34(97.1 \%)$ & $1(2.9 \%)$ & 0.00 & $32(91.4 \%)$ \\
$\begin{array}{l}\text { I always attend village assembly meeting } \\
\text { for EDP }\end{array}$ & 0.00 & 0.00 & $25.7 \%)$ & 0.00 \\
\hline
\end{tabular}

Source: Field data 2017

The findings in Table 4.5 indicates that community involvement in setting priorities, planning of EDP as being a problem in Kiroka village where $85.7 \%$ community members strongly disagreed that they were not involved in setting priorities. Despite the lack of community members' involvement in setting priorities they were involved at the approval stage. This is according to $80 \%$ of the respondents who strongly agreed that they were involved during approval of the EDP in the village. This shows that most of the plans are prepared by only village leaders while community members are involved in the approval stage only. This indicates that the Participatory O\&OD methodology as provided in the Planning Methodology Rural Process 2007 is not followed.

It was further found that, the dialogue with facilitators to prepare education planning was not conducted, as disagreed by $85.7 \%$. However, $88.6 \%$ respondents agreed that sensitization for EDP was conducted. Sensitization was done in the village meetings during approval of the EDP. However sensitization was not for launching O\&OD for EDP.

It was further revealed that there was extra ordinary village assembly for approval of EDP, as was strongly agreed by $97.1 \%$ of all respondents; however most respondents $(91.4 \%$ ) strongly disagreed that extra ordinary village assembly for launching EDP had been conducted. This indicates that the planning process was dominated by village leaders and 
village members were involved only at approving the plans. Despite some evidence for the community involvement in the approval of EDP, $71.4 \%$ disagreed that they do not attend the village meetings in most often. This suggests poor attendance for the villagers in the village meetings held. The study found that villagers mostly attend village meeting when the village leaders have prepared lunch. This was noted in the interview with village chairperson as he pointed out that:

We sometimes prepare lunch during village meeting, when the lunch is prepared many villagers attend the meeting, but if no lunch few villagers attend the meetings, when we have a special issue we always prepare lunch in order to attract many villagers attend the meetings. (Village chairperson, Kiroka village: March 2017).

Although the village revenue and expenditure report was made to the public in the village meetings, the information was shared to the villagers as a tool to influence them to provides more contributions. In the interview with one of the council member it was quoted that: "...We are sharing village revenue and expenditure report to the public for the purpose of evaluating community contributions and how the projects is moving, however this is done always when the projects are not moving well.. "(Village council members 5, Kiroka village: March, 2017)This indicates that expenditure reports are shared to the public only when the projects are not doing well.

\subsubsection{Experiences from Kiziwa Villages}

In assessing wheatear community members are involved in EDP in Kiziwa village questionnaires were administered to 35 community members. The communities were asked to rate different activities performed during EDP at the scale of strongly agreed, disagree, agree and strongly disagree. The purpose for asking the questions was to assess whether the community members are involved fully and whether. The result is presented in table 4.6.

Table 4.6. Community involvement in Kiziwa village $(\mathrm{N}=5)$

\begin{tabular}{lllll}
\hline \multicolumn{1}{c}{ Questions } & \multicolumn{1}{c}{$\begin{array}{c}\text { Strongly } \\
\text { agree }\end{array}$} & Agree & Disagree & $\begin{array}{c}\text { Strongly } \\
\text { disagree }\end{array}$ \\
\hline $\begin{array}{l}\text { I have been involved in setting priorities } \\
\text { for EDP }\end{array}$ & $1(2.9 \%)$ & $1(2.9 \%)$ & $1(2.9 \%)$ & $32(91.4 \%)$ \\
$\begin{array}{l}\text { EDP were formulated by village leaders } \\
\text { only }\end{array}$ & $5(14.2 \%)$ & & $2(5.7 \%)$ & $28(80 \%)$ \\
$\begin{array}{l}\text { Community members were involved in } \\
\text { collecting relevant data for EDP }\end{array}$ & & $5(14.3 \%)$ & $25(71.4 \%)$ & $5(14.3 \%)$ \\
$\begin{array}{l}\text { Dialogue with facilitators to prepare } \\
\text { education planning was conducted }\end{array}$ & 0.00 & 0.00 & $5(14.2 \%)$ & $30(85.7 \%)$ \\
$\begin{array}{l}\text { Sensitization for EDP was conducted } \\
\begin{array}{l}\text { Extra ordinary village assembly for } \\
\text { launching EDP was conducted }\end{array}\end{array}$ & 0.00 & $4(11.4 \%)$ & $25(71.4 \%)$ & $6(17.1 \%)$ \\
$\begin{array}{l}\text { Extra ordinary village assembly for } \\
\text { approval was conducted }\end{array}$ & 5.00 & 0.00 & $1(2.9 \%)$ & $34(97.1 \%)$ \\
$\begin{array}{l}\text { I always attend village assembly meeting } \\
\text { for EDP }\end{array}$ & 0.00 & $5(14.3 \%)$ & 0.00 & $30(85.7 \%)$ \\
\hline
\end{tabular}


Source: Field data 2018

The findings above indicates that, community members are not involved in setting priorities for EDP, as for $91.4 \%$ of the respondents who strongly disagreed that they were not involved in setting priorities. This shows that most of the plans are prepared by village leaders approved by few community members. As the result community members do not perform some of their roles are required in the Participatory Planning Methodology Rural Process 2007.

It was further found that the dialogue with facilitators to prepare education planning was not conducted; this was strongly disagreed by $85.7 \%$ of respondents. Up to $71.4 \%$ of respondents disagreed that sensitization for EDP was not conducted, which could be due to less attendance of members in the village meeting and minimal sensitisation. It was further found that there was extra ordinary village assembly for approval of EDP this was agreed by $71.4 \%$ of all respondents, however most respondents did not attend the meeting, this was strongly disagreed by $85.7 \%$, this causes EDP to be approved by village leaders. Basing on community involvement in EDP it seems the roles of community members are not conducted as stipulated by O\&OD planning guideline of 2007. This was due to the reason that community members were involved only in the approval and implementation stages and few community members attended village meetings.

\section{Discussions}

Education planning process in both Kiziwa village and Kiroka village are similar. In all the villages planning process is conducted by school committees then the plans are taken to the village council. The village council discusses and approves plans. The plans are then taken to the village assembly for approval. The planning process conducted in Kiziwa and Kiroka villages in Kiroka ward is similar to the plans conducted in other parts of Tanzania in the sense that planning process is done by community leaders. The community members are involved in the implementation stage. In the study by Mabula (2007) on participatory approach and development planning process in Maswa district Shinyanga Tanzania. The study found that, community members were not involved in planning stages they were involved in the implementation stages. In the study area similar result were found as community members were involved in the approval and implementation stages. Furthermore, the study by Kambuga (2013) on the role of Community Participation in the Ongoing Construction of Ward Based Secondary Schools drawing lessons from Tanzania. The study found that villagers are generally not actively involved in decision making, planning, monitoring and evaluation processes.

In the study by Mabula, the constraints for community involvement mentioned include inadequate fund and poor accountability and transparent of some leaders. In the current study, one of the reasons for low community involvement was low knowledge among community leaders and community members. The study by Mnaranara (2013) on the importance of community participation in ongoing construction of primary schools in Mlali and Mzumbe ward Morogoro region found low awareness among community members as one of the factors for low participation. This was also a reason for low participation in the study area. 
Community leaders had no knowledge on how to involve community members using O\&OD planning methodology. Low knowledge was also revealed during making preferences for education development. Both primary and secondary schools in Kiroka and Kiziwa village had a lot of education projects. No preferences was made, for instance Kiroka secondary had about (6) development projects. Lack of preferences in EDP in the village shows presence of low knowledge among community leaders. Another reason for low community participation is cultural practices as noted by Waweru (2001) that, culture may encourage and motivate community to take part in community planning. The study area was dominated by traditional culture which discouraged community members to participate in EDP. Unlike Kiroka, in Kiziwa village the community members are less interested in attending community meetings for approving plans this was due to the low awareness and less interests in education matters and political opposition.

Table 4.5 in chapter four has presented frequency and percentages of community involvement in EDP at Kiroka village and Table 4.7 as well has present frequency and percentages of community involvement in EDP at Kiziwa village. In both villages visited, extra ordinary village assembly for launching EDP was notbeing conducted. Community members were not involved in setting priorities, however involved in the extra ordinary village assembly for approval of O\&OD conducted.

This study is similar to the findings by Rutasigwa's (2013) study on the effects of community participation on access to quality secondary education and post ordinary level education in Tanzania, which focused in Bukoba municipality. The study found that, in most of the wards community involvement in the construction of school infrastructure was not promising. However involvement was done only at the approval stage where members were involved in the general assembly to approve the education plans. Despite the practice, village meetings were held to approve the education plans. The findings revealed that few community members attended the meetings in both villages. This was due to the low knowledge among community members and bad traditional culture which discouraged girls to study.

Further in the study Chirenje (2013) on Local communities' participation in decision-making processes through planning and budgeting in African countries. The findings revealed that community were more involved in the implementation of natural resources programme but lacked ownership. This was similar to the current study findings where community members were involved in the implementation stages only. The findings in the study by Mollel (2010) indicated that O\&OD has failed in bringing popular participation and sought empowerment. The findings were similar to the present findings at Kiziwa and Kiroka ward. This is true in the sense that the village has never received facilitators for launching O\& OD process. The complaints from the council headquarter emanate from the approach as it requires a lot of time and fund and the council had insufficient fund for this.

One of the reasons impeding community involvement using O\&OD is lack of technical and physical capacity which constrains many people from substantial information on the importance of participatory planning. This is true in sense that community members are not aware on their actual role and why they should get involved in EDP. Community members, 
village and ward leaders are inhibited from making plans that meets the prescribed standards due to inadequate skills or ${ }^{6}$ know how' in collecting data, and in compiling whatever data is available for the purposes of planning.

The current findings are similar to the findings by Mefunya (2011) in the study on the opportunities and obstacles to development planning method used in Tanzania's decentralized local governments with focus at Rulenge and Murusagamba Wards in Ngara District of Kagera Region. The study found that structural and management factors inhibit the use of O\&OD in development planning. The structural issues mentioned include lack of technical capacity among ward facilitators and community members. Community members and ward facilitators lacked knowledge about O\&OD.

The findings in Table 4.5 and 4.7 showed that, few community members attended the village meetings. Massoi\& Norman (2009) conducted a study on decentralisation by devolution in Tanzania, with reflections on community involvement in the planning process in Kizota Ward in Dodoma. The study found that planning process at grassroots level is still minimal and ineffective, as the Mitaa residents were not involved in the planning process. Community leaders claimed that few members attended village meetings hence difficult to be involved. However few community members attended village meetings in Kiroka and Kiziwa villages. The meetings were held for the purpose of approving EDP not for setting priorities. Therefore this cannot be the reason for low community involvement in EDP.

Reference is also drawn in the study by Kambuga (2013) on the role of Community Participation in the Ongoing Construction of Ward Based Secondary Schools in Tanzania. The study found that villagers are generally not actively involved in decision making, planning, monitoring and evaluation processes. Less involvement of community members in setting priorities in the study area led poor EDP since few members contribute for EDP. The findings concurs with the findings by Simon (2014) on participatory planning in budgeting process; he found that community participation in planning is still very low as the process is owed by leaders and not community members. In this study EDP process was dominated by community leaders. This was led by low knowledge of community leaders on the roles of community members.

\section{Conclusions}

The findings provide evidence of low community participation of community members in EDP. It was noted a necessity that community members are to be involved in all stages. It was noted in the study that, they were only involved in the approval and implementation stages only and that plans were prepared by community leaders and approved by community members

\section{References}

Arnstein, S. (1969). A ladder of citizen participation. AIP Journal, 35(4), July 1969, 216-24. https://doi.org/10.1080/01944366908977225

Bailey, D. K. (1998). Methods of Social Research. The Press Collier McMillan Publisher: 
London.

Certo, S. (2000). Modern management. Upper Saddle River, N.J: Prentice Hall.

Chaligha, A. (2008). Local Government and Citizen Participation in Tanzania: From a local government reform perspective. Dar Es Salaam: REPOA.

Chirenje, L. I. (2013). Local communities' participation in decision-making processes through planning and budgeting in African countries. Chinese Journal of Population Resources and Environment, 11(1), 2013. https://doi.org/10.1080/10042857.2013.777198

Harold, K. C., \& O’Donnell, P. (1968). Management: An Analysis of Managerial Functions. McGraw-Hill: New York.

Imparato, I., \& Jeff, R. (2003). Slum Upgrading and Participation: Lessons from LatinAmerica. Washington, D.C.: World Bank. https://doi.org/10.1596/0-8213-5370-5

Kambuga, Y. (2013). The Role of Community Participation in the Ongoing Construction of Ward Based Secondary Schools Lessons of Tanzania. International Journal of Education and Research, 1(7).

Mabula, B. J. (2007). Participatory approach and development planning process in Maswa district, Shinyanga

Tanzania. http://www.suaire.suanet.ac.tz:8080/xmlui/handle/123456789/197

Massoi, L., \& Norman, A. S. (2009) Decentralisation by devolution in Tanzania: Reflections on community involvement in the planning process in Kizota Ward in Dodoma. Journal of Public Administration and Policy Research, 1(7), 133-140.

Matete, R. (2016). Challenges Facing Primary Education under Decentralization of Primary School Management. International Journal of Humanities and Social Sciences. ISSN 2220-8488. www.Ijhssnet.com

Max, J. O. (1991). The Development of Local Government in Tanzania. Dar es-salaam.

Mollel, A. H. (2010) Participation for Local Development. The reality of Decentralization in Tanzania http://www.rug.nl/research/portal/files/14672739/21 complete.pdf

Munaranara, T. L. (2010) Importance of Community Participation in Ongoing Contructon of Primary Schools in Mlali and Mzumbe Ward, Morogoro Region https://brage.bibsys.no/xmlui/bitstream/handle/11250/135155/Theresia

Oyugi, N., \& Kibua, T. N. (2006). Planning and Budgeting at the Grassroots Level: The Case of Local Authority Service Delivery Action Plans. IPAR. Nairobi

PMO-RALG. (2004). Planning guidelines for villages and mitaa. DODOMA. Prime Minister's Office -Regional and Local Government. Dar es Salaam: Educational Publishers and Distributors Ltd.

PMO-RALG. (2005). Opportunities and Obstacles to Development Programme (O\&OD). Dodoma: Prime Ministers Office, Regional Administration and Local Government. 


\section{Macrothink}

International Journal of Human Resource Studies

ISSN 2162-3058 2019, Vol. 9, No. 1

PMO-RALG. (2007). Historical perspective on participatory planning in Tanzania. Dodoma: Prime Minister's Office, Regional Administration and Local Government.

PMO-RALG. (2007b). Opportunities and Obstacles to Development: A community participatory planning methodology. Dodoma: Prime Ministers Office, Regional Administration and Local Government.

PMO-RALG. (2008). The study on improvements of opportunities and obstacles to development planning process. Final report, March 2008. Japan International Cooperation Agency (JICA).

Rutasigw, O. (2013) Effects of Community Participation on Access of Quality Education and Post Ordinary Level Education Bukoba Tanzania.

Shivji, I. G., \& Maina, P. C. (2003), Village Democracy Initiative Report. Dodoma: The President's Office.

Shivji, I. G., \& Maina, P. C. (2003). Village Democracy Initiative Report. Dodoma: The President's Office, Regional Administration and Local Government.

Waweru, R. (2001) Factors Which Promote Community Participation in the Community Driven Development Approach. International Journal of Humanities \& Social Science Studies, 2349-6959.

\section{Copyright Disclaimer}

Copyright for this article is retained by the author(s), with first publication rights granted to the journal.

This is an open-access article distributed under the terms and conditions of the Creative Commons Attribution license (http://creativecommons.org/licenses/by/4.0/). 